\title{
A Case of Metastatic Malignant Melanoma Presenting as Subcutaneous Posterior Neck Mass
}

\author{
Sung Hwan Lim ${ }^{1}$, Beom Mo Koo ${ }^{1}$, Min A Kim², and Seung Woo Kim ${ }^{1}$ (iD \\ ${ }^{1}$ Departments of Otorhinolaryngology-Head and Neck Surgery, ${ }^{2}$ Pathology, Veterans Health Service Medical Center, Seoul, Korea
}

\author{
피하 후경부 종물로 나타난 전이성 악성흑색종 1 예 \\ 임성환 ${ }^{1} \cdot$ 구범모 $^{1} \cdot$ 김민아 $^{2} \cdot$ 김승우 ${ }^{1}$ \\ 중앙보훈병원 이비인후과, ${ }^{1}$ 병리과 ${ }^{2}$
}

\author{
Received March 18, 2019 \\ Revised April 13,2019 \\ Accepted April 18, 2019 \\ Address for correspondence \\ Seung Woo Kim, MD \\ Department of Otorhinolaryngology- \\ Head and Neck Surgery, \\ Veterans Health Service \\ Medical Center, \\ 53 Jinhwangdo-ro 61-gil, \\ Gangdong-gu, Seoul 05368, Korea \\ Tel +82-2-2225-1384 \\ Fax +82-2-2225-1385 \\ E-mail entzzang1020@daum.net
}

\begin{abstract}
Malignant melanoma can be classified as both cutaneous and mucosal types. The former comprises more than $98 \%$ of all melanomas and is related to ultraviolet exposure, whereas the latter occupies only $1.3 \%$. More than half of mucosal melanoma arises in the head and neck region, and the sinonasal tract is also one of its predilection sites. On the other hand, the metastatic melanoma of head and neck is lower incidence than primary lesion and the unknown primary site is about two to five percent. Moreover, a lymphatic metastasis to the posterior neck is a more unusual clinical pattern. A 71-year-old man with a solitary subcutaneous posterior neck mass visited our clinic. He was confirmed with metastatic melanoma in the lymph node through excisional biopsy. However, the primary site was not found with whole radiologic examinations. We report a very rare disease entity with a brief literature review.
\end{abstract}

Korean J Otorhinolaryngol-Head Neck Surg 2019;62(7):416-9

Key Words Malignant melanoma $\cdot$ Lymphatic metastasis $\cdot$ Neck.

\section{서 론}

악성흑색종은 멜라닌 세포가 있는 모든 부위에 발생할 수 있으나, 대부분 피부에서 발생하고 $1.3 \%$ 정도만 점막에서 발 생한다. ${ }^{1,2)}$ 전체 악성흑색종에서 약 $20 \%$ 가 두경부에서 발생하 고, 점막형 흑색종은 $50 \%$ 이상이 비강, 비부비동 및 구강에 서 발생한다. ${ }^{2)}$ 경부의 전이성 악성흑색종은 드물며, 특히 원 발지 불명은 전체 악성 흑색종의 2 5\% 정도로 매우 드물다. ${ }^{3)}$

71세 남자가 피하 후경부 종물에 대해 절제생검을 위해서 피부과에서 본과로 의뢰되어 림프절로 전이된 원발지 불명의 악성흑색종으로 최종 진단되었다. 본 증례가 후경부에 발생 한 원발지 미상의 전이성 악성흑색종의 국내에서 첫 보고로 사료되어 문헌고찰과 함께 보고하고자 한다.

This is an Open Access article distributed under the terms of the Creative Commons Attribution Non-Commercial License (https://creativecommons.org/licenses/by-nc/4.0) which permits unrestricted non-commercial use, distribution, and reproduction in any medium, provided the original work is properly cited.

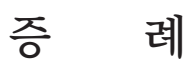

71세 남자 환자가 내원 5개월 전부터 발생한 피하 후경부 종물로 피부과에서 의뢰되었다. 과거력상 $\mathrm{B}$ 형 간염 보균자이 며, 흡연 및 음주력은 없었다. 다른 피부질환의 병력은 없었 으며, 가족력상 특이사항은 없었다. 종물은 3개월 전부터 크 기가 점차 증가하였고 통증이 동반되었으며, 직전 피부과에 서 시행한 펀치생검에선 특이 소견 없었다. 신체 검사에서 좌 측 후경부 피하층에 약 $2 \times 2 \mathrm{~cm}$ 크기의 압통을 동반하며 비 교적 단단하고 피부 표면에 홍반성 구진이 동반된 고정성 종 물이 촉진되었다(Fig. 1). 경부의 다른 부위에 비정상적으로 촉지되는 종물은 없었고, 인후두 내시경 소견에서 특이 소견 은 없었다. 전신상태를 평가하는 ECOG(Eastern Cooperative Oncology Group) 활동도는 0점이었으며, 발열 및 체중 감소 등의 전신 증상도 없었다. 영상학적 평가를 위하여 시 행한 초음파 검사에서 좌측 후경부에 $1.9 \times 1.4 \mathrm{~cm}$ 크기의 경 
계가 분명하고 내부에 혈류 흐름이 있는 저에코 음영의 균질 한 종물이 관찰되었고(Fig. 2A), 경부 전산화 단층 촬영에서 는 좌측 후경부에 $2.1 \times 1.4 \mathrm{~cm}$ 크기의 경계가 명확하고 주변 부는 조영 증강되며 중심부가 저밀도 소견을 보이는 피하 종 물이 관찰되었다(Fig. 2B and C).

후경부에 발생한 표피낭종, 지방종, 섬유종, 모기질종 및 악성 종양 등의 가능성을 염두에 두고 절제생검을 시행하였 다. 종물과 가장 유착이 심한 부위에서 $5 \mathrm{~mm}$ 정도 위와 아 래로 타원형 모양으로 피부를 절개하였다. 종물은 주변부와 유착이 있었으며, 하방의 근육층과 박리한 후 유착이 심한 피부를 포함하여 제거 하였으며, 중등도의 출혈이 있었다. 병 리 육안 소견에서 종물의 경계는 분명하고 절단면은 비균질 한 양상이었다(Fig. 3A and B). 현미경 소견에서는 진피 내 유상피세포와 방추세포가 다수 관찰되었고(Fig. 3C-E), 면 역 조직화학 염색에서 HMB-45, Melan A, S-100에 양성을 보여(Fig. $3 \mathrm{~F}$ ) 최종적으로 림프절에 전이된 전이성 악성흑색 종으로 진단되었다. 원발지를 찾기 위해 림프액의 배액 경로 를 고려하여 후두부 전체의 피부를 시진 및 촉진하였지만 특 이점은 없었고, 흥부, 복부 전산화 단층 촬영 및 양전자단층 촬영술 등을 시행하였으나, 역시 특이 소견 없었다. 이상의 소견들을 종합하여 림프절로 전이된 원발지 불명의 악성 림
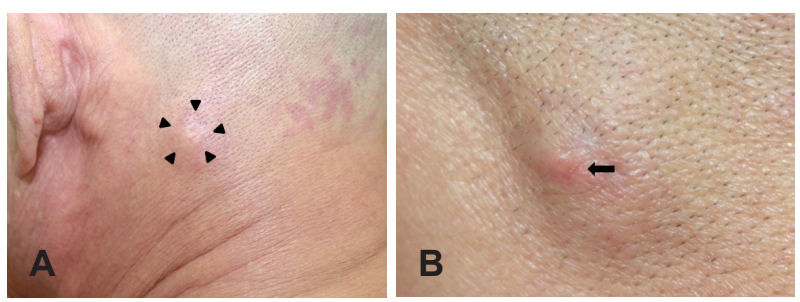

Fig. 1. External photograph shows a solitary firm, round shaped subcutaneous $2 \times 2 \mathrm{~cm}$ sized mass on left posterior neck (arrowheads) (A) and a erythematous to skin colored papule on the mass (arrow) (B).
프종으로 최종 진단되었으며, 병기는 Stage $\mathrm{lV}$ 로 평가되었다. 근치 수술을 위해 후외측 경부절제술(posterolateral neck dissection)을 권유하였으나, 환자분이 강하게 거부하여 혈액 종양내과로 의뢰하여 표적치료제인 Nivolumab(Opdivo ${ }^{\circledR}$, Ono Pharma, Osaka, Japan)으로 치료를 하였고, 6개월이 지난 현재까지 재발 소견 없이 경과관찰 중이다.

\section{고 찰}

악성흑색종은 아시아보다는 백인에서 흔하고, 태양광 노 출이 발병 위험성을 높일 수 있어 두경부에서는 안면부에서 호발한다. ${ }^{1,45}$ 대부분 피부에서 발생하지만 약 $0.8 \sim 1.3 \%$ 는 점 막에서 발생하며, 후자는 세포분열의 빈도가 높고 혈관이나 림프절 침윤이 흔하여 고 악성도로 예후가 불량하다. ${ }^{2,6)}$ 악성 흑색종은 재발과 전이가 흔하며, 혈행성보다 림프절을 통한 전이가 먼저 발생한다. ${ }^{7)}$ 전이의 형태로는 원발 흑색종에서 5 $\mathrm{cm}$ 이내에 발생하는 위성전이(satellite metastasis)와 원발지 에서 $5 \mathrm{~cm}$ 이상 떨어진 곳에서부터 국소림프절 사이에서 전 이가 일어나는 통과전이(in-transit metastasis), 국소 림프절 전이 및 원격전이 등으로 나눌 수 있다.7) 192 명을 대상으로 한 보고에서 전이부위는 하지가 가장 많았고 두피, 팔, 안면 등의 순으로 발생하였고, 경부는 드물었다. ${ }^{3)}$ 원발지를 알 수 없는 전이성 악성흑생종은 전체 악성흑색종의 약 2 5\%를 차지하며 국내에서는 측경부에 발생한 2예만 보고되었고, ${ }^{8,9)}$ 본 증례처럼 후경부에서 발생한 국내 보고는 없었던 것으로 사료된다.

림프절 전이는 원발지에 따라서 다양하며, 두경부에서는 주 로 이하선과 경부 $\mathbb{I}$ 구역이 흔한 전이부위이며, ${ }^{5,10)} \mathrm{V}$ 구역 및 후두부 림프절은 후두부 두피에서 전이되는 경우가 흔하다. ${ }^{5)}$ 악성흑색종의 원격 전이는 간, 뇌, 폐 및 골 등에 흔하다. ${ }^{9)}$ 원
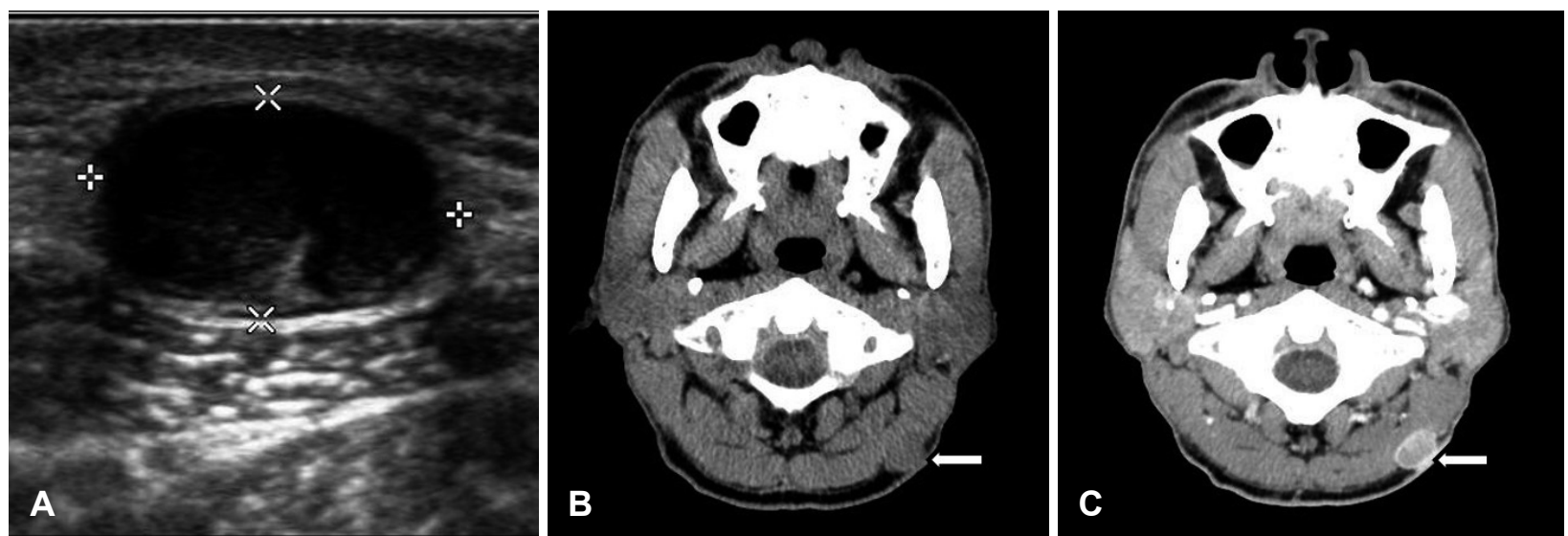

Fig. 2. Radiologic findings. (A) Transverse scan of neck ultrasonography show $1.9 \times 1.4 \mathrm{~cm}$ sized hypoechoic ovoid mass with well-defined margin in subcutaneous layer (asterisks). (B) Non-enhanced axial neck CT scan shows $2.1 \times 1.4 \mathrm{~cm}$ sized hypo attenuation mass in left posterior neck area (arrow). (C) Enhanced axial neck CT scan shows peripheral rim enhanced mass in above same area (arrow). 

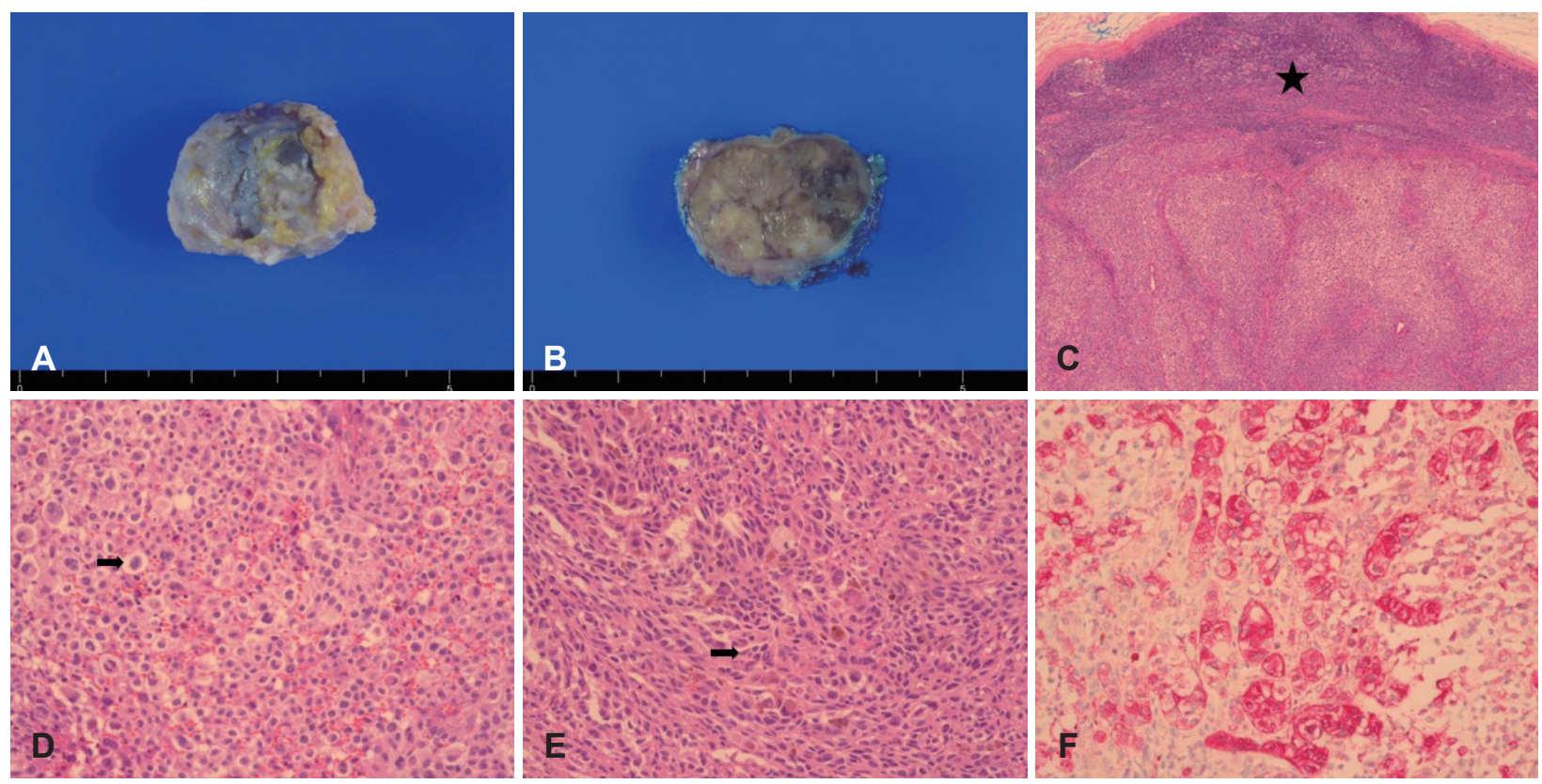

Fig. 3. Pathological findings. (A, B) The whole and cut surface of specimen show that $2.2 \times 1.6 \mathrm{~cm}$ sized mass with internal non-homogenous appearance. (C) Normal lymphoid tissues (black star) are observed above, and metastatic tumor cell with clear borderline throughout the dermis are observed below (H\&E, $\times 40)$. (D) It shows round, epithelioid-shaped tumor cells (black arrow) and clear to eosinophilic cytoplasm (H\&E, $\times 200)$. (E) Spindle-shaped tumor cells (black arrow) arranged in long fascicles are noted in dermis (H\&E, $\times 200)$. (F) The cytoplasm of melanocyte was stained with anti-HMB-45 and it was revealed with light brown color (HMB-45, $\times 400)$. H\&E: hematoxylin and eosin.

발지 불명인 경우의 원인으로는 인접 림프절 전이 후 원발병 소의 자연 소멸, 원발병소를 발견하지 못한 경우 및 림프절 내 비정상적인 염색세포의 악성 변화 등의 가설이 있다.) 병리조 직학적으로 전이성 악성흑색종은 비정형 멜라닌세포가 표피 의 침범 없이 진피와 피하지방층에 존재하며, 종양 내 멜라닌 색소를 확인하면 진단되지만 무멜라닌 성 흑색종은 S-100, HMB-45 등의 면역염색을 통해서 진단할 수 있다. ${ }^{79)}$

악성흑색종이 원발 또는 전이성 병변 인지를 구분하는 것 은 예후 및 치료 방법이 다르기 때문에 중요하다. ${ }^{6}$ 조기 발견 시에는 광범위 절제연을 두고 절제술을 시행하는 것이 치료 원칙이지만, 병변의 위치, 범위 및 전이 여부 등에 따라서 수 술이 어려울 수 있다. ${ }^{6}$ 수술이 불가능하거나, 재발 또는 원격 전이의 경우 항암화학요법으로 세포독성 항암제인 dacarbazine를 단독 혹은 vincristine, CCNU[1-(2-chloroethyl)3-cyclohexyl-1-nitrosourea], dactinomycin, belomycin 등 과 병합하여 사용하거나, ${ }^{2)}$ interleukin-2 등을 이용한 면역 치료요법이 가능하나 치료 반응률이 낮고 심각한 독성으로 제한이 있다.1) 최근에는 흑색종의 발생 및 진행에 관여하는 B-Raf proto-oncogene(BRAF), neuroblastoma RAS viral oncogene homolog(NRAS), mast/stem cell growth factor receptor $\operatorname{Kit}(C-K I T)$ 와 관계되는 분자기전과 면역세포의 종 양세포에 대한 면역회피(immune escape)에 관여하는 cytotoxic T lymphocyte-associated antigen 4(CTLA-4), pro- grammed death receptor-1(PD-1), programmed deathligand 1(PD-L1)을 표적으로 하는 다양한 표적치료제를 이 용한 치료를 하고 있다.1) 표적치료제는 기존의 항암치료요법 과 비교하여 유의하게 생존율을 향상시킨다고 보고되었다.) 본 증례에서 사용된 표적치료제인 Nivoluamb(Opdivo $\left.{ }^{\circledR}\right)$ 는 $\mathrm{T}$ 세포 증식과 활성화를 억제하는 PD-1에 대한 항체로 $\mathrm{T}$ 세 포를 활성화시켜 면역계가 암을 제거할 수 있게 해주는 기전 의 약물이다. ${ }^{11}$

저자들은 본 증례를 통해 미세한 피부변화를 동반하는 표 층 경부 종물의 경우 감별진단에 악성흑색종에 의한 림프절 로의 전이성 병변을 염두에 두어야 하고, 신속한 조직학적 확 진을 통해 조기에 치료를 시작하는 것이 예후에 중요하다는 교훈을 얻었다.

\section{ORCID}

Seung Woo Kim https://orcid.org/0000-0002-7931-6977

\section{REFERENCES}

1) Lee SJ, Chae YS. New cystemic treatment for malignant melanoma. Korean J Med 2013;85(4):357-63.

2) Do HW, Park JS. Comparison study for mucosal malignant melanoma of head and neck according to primary sites. Korean J Otolaryngol 1998;41(8):1054-8.

3) Plaza JA, Torres-Cabala C, Evans H, Diwan HA, Suster S, Prieto VG. Cutaneous metastases of malignant melanoma: a clinicopathologic study of 192 cases with emphasis on the morphologic spectrum. 
Am J Dermatopathol 2010;32(2):129-36.

4) Kienstra MA, Padhya TA. Head and neck melanoma. Cancer Control 2005;12(4):242-7.

5) Newlands C, Gurney B. Management of regional metastatic disease in head and neck cutaneous malignancy. 2. Cutaneous malignant melanoma. Br J Oral Maxillofac Surg 2014;52(4):301-7.

6) Shiga K, Ogawa T, Kobayashi T, Ueda S, Kondo A, Nanba A, et al. Malignant melanoma of the head and neck: a multi-institutional retrospective analysis of cases in northern Japan. Head Neck 2012; 34(11):1537-41.

7) Jang MS, Han SH, Kim JH, Lee KH, Park JB, Kim ST, et al. Epidermotropic metastatic malignant melanoma. Koeran J Dermatol 2015;53(1):53-7.

8) Bowen GM, Chang AE, Lowe L, Hamilton T, Patel R, Johnson
TM. Solitary melanoma confined to the dermal and/or subcutaneous tissue: evidence for revisiting the staging classification. Arch Dermatol 2000;136(11):1397-9.

9) Woo JH, Yoon BK, Kim DY, Park SH. Two cases of malignant melanoma with nodal metastasis from unknown primary site. Korean J Otorhinolaryngol-Head Neck Surg 2009;52(1):75-8.

10) Rahimi-Nedjat RK, Al-Nawas B, Tuettenberg A, Sagheb K, Grabbe S, Walter C. Sentinel lymph node biopsy in malignant melanoma of the head and neck. Craniomaxillofac Surg 2018;46(6): 1027-31.

11) Mashima E, Inoue A, Sakuragi Y, Yamaguchi T, Sasaki N, Hara $Y$, et al. Nivolumab in the treatment of malignant melanoma: review of the literature. Onco Targets Ther 2015;8:2045-51. 